Available online at https://jurnal.stmikroyal.ac.id/index.php/jurdimas

\title{
PENINGKATAN PEMANFATAN PERAN TEKNOLOGI INFORMASI BAGI MASYARAKAT SEKITAR POLSEK PORSEA KAB.TOBA SAMOSIR
}

\author{
Iin Almeina Lubis ${ }^{1 *}$, Romy Aulia ${ }^{1}$, Febby Madonna Yuma $^{1}$ \\ ${ }^{1}$ Program Studi Sistem Informasi, STMIK Royal Kisaran \\ Email : *lubisiinalmeina@gmail.com
}

\begin{abstract}
Abstrack: Community Service Activities in the form of training on the use of the internet at Porsea Sub-District of Toba Samosir District aim to increase the knowledge of the surrounding community about internet technology and the benefits of the internet and encourage surrounding communities to be able to independently manage and utilize network and internet functions. The main target in this community service is the community around Porsea Sub-District, Toba Samosir District. The training method used is a form of training in the classroom using the lecture method, discussion and question and answer. The lecture method used is intended to provide a theoretical explanation of internet and network material. The discussion method is used to explore the understanding of the surrounding community about the material given in lectures. Practice methods are used to show how to use the internet properly and correctly. The benefits of this training activity are that the surrounding community is able to use the internet and the network for positive and useful things.
\end{abstract}

Keywords: Internet, Benefits, Training, Networks

Abstrak : Kegiatan Pengabdian Pada Masyarakat berupa pelatihan pemanfaatan internet di Polsek Porsea Kab.Toba Samosir bertujuan untuk meningkatkan pengetahuan masyarakat sekitar terhadap teknologi internet dan manfaat dari internet serta mendorong masyarakat sekitar agar mampu dengan mandiri mengelola dan memanfaatkan fungsi jaringan dan internet. Khalayak sasaran dalam pengabdian masyrakat ini adalah masyarakat sekitar Polsek Porsea Kab.Toba Samosir. Metode pelatihan yang digunakan adalah bentuk pelatihan di dalam kelas dengan menggunakan metode ceramah, diskusi dan tanya jawab. Metode ceramah yang digunakan dimaksudkan untuk memberikan penjelasan secara teori terhadap materi internet dan jaringan. Metode diskusi digunakan untuk menggali pemahaman masyarakat sekitar terhadap materi yang diberikan secara ceramah. Metode praktek digunakan untuk menunjukan langsung cara menggunakan internet yang baik dan benar. Manfaat yang diperoleh dari kegiatan pelatihan ini adalah masyarakat sekitar mampu menggunakan internet dan jaringan untuk hal-hal positif dan bermanfaat.

Kata kunci : Internet, Manfaat, Pelatihan, Jaringan 
Jurdimas (Jurnal Pengabdian Kepada Masyarakat) Royal

Vol. 2 No. 2, Juli 2019, hlm. 177 - 180

DOI: https://doi.org/10.33330/jurdimas.v2i2.375

ISSN 2614-7912 (Print)

ISSN 2622-3813 (Online)

Available online at https://jurnal.stmikroyal.ac.id/index.php/jurdimas

\section{PENDAHULUAN}

Seiring dengan kemajuan ilmu pengetahuan dan teknologi serta komputerisasi, lebih khusus pada perangkat lunak, maka baik secara langsung maupun tidak dunia pendidikan juga menuai dampaknya.

Media dalam bahan ajar memiliki fungsi sebagai alat bantu untuk memperjelas pesan yang disampaikan mentor. Media juga berfungsi untuk pembelajaran individual dimana kedudukan media sepenuhnya melayani kebutuhan belajar masyarakat sekitar (pola bermedia). Menurut Briggs (1977) media pembelajaran adalah sarana fisik untuk menyampaikan isi/materi pembelajaran seperti : buku, film, video dan sebagainya. Proses pembelajaran merupakan proses komunikasi dan berlangsung dalam suatu sistem, maka media pembelajaran menempati posisi yang cukup penting sebagai salah satu komponen sistem pembelajaran. Tanpa media, komunikasi tidak akan terjadi dan proses pembelajaran sebagai proses komunikasi juga tidak akan bisa berlangsung secara optimal.

Internet (kependekan

dari interconnection-networking) adalah seluruh jaringan komputer yang saling terhubung menggunakan standar sistem global Transmission Control Protocol/Internet Protocol Suite (TCP/IP) sebagai protokol pertukaran paket (packet switching communication protocol) untuk melayani miliaran pengguna di seluruh dunia.

Salah satu program Polsek Porsea Kab.Toba Samosir yaitu mengutamakan perkembangan dan keterampilan masyarakat sekitar. Keterampilan yang dimiliki merupakan hasil dari pembelajaran di sekolah. Selama ini cara pembelajaran secara tatap muka masih memiliki beberapa kelemahan. Salah satunya adalah perbedaan dari setiap masyarakat sekitar dalam menangkap dan mencerna materi pembelajaran. Ada masyarakat sekitar yang mengerti, ada yang kurang mengerti, bahkan ada yang tidak mengerti sama sekali. Oleh karena itu, internet memiliki peranan penting dalam hal ini, yaitu dapat membantu mengatasi permasalahan dan kelemahan yang ada. Internet dapat membantu masyarakat sekitar mendapatkan ilmu dari luar sekolah, sehingga masyarakat sekitar dapat menangkap dan mencerna materi yang diajarkan oleh Mentor.

Berdasarkan permasalahan yang dijelaskan di atas, maka pengabdian masyarakat ini dilaksanakan untuk memberikan pelatihan mengenai pemanfaatan internet bagi masyarakat.

\section{METODE}

Metode pelaksaan dalam pengabdian masyarakat ini adalah dengan cara melaksanakan kegiatan pelatihan dalam bentuk presentasi, dengan menjelaskan dasar teori dan praktek langsung yang berlokasi di Polsek Porsea Kab.Toba Samosir.

\section{PEMBAHASAN}

Pada pelaksanaan Pengabdian Masyarakat ini diberikan terlebih dahulu brainstorming mengenai pengertian jaringan internet. 
Jurdimas (Jurnal Pengabdian Kepada Masyarakat) Royal

Vol. 2 No. 2, Juli 2019, hlm. 177 - 180

DOI: https://doi.org/10.33330/jurdimas.v2i2.375

ISSN 2614-7912 (Print)

ISSN 2622-3813 (Online)

Available online at https://jurnal.stmikroyal.ac.id/index.php/jurdimas

Manfaat yang didapat dalam membangun jaringan internet, yaitu:

1. Sharing resources

Sharing resources bertujuan agar seluruh program, peralatan atau peripheral lainnya dapat dimanfaatkan oleh setiap orang yang ada pada jaringan komputer tanpa terpengaruh oleh lokasi maupun pengaruh dari pemakai.

2. Media Komunikasi

Jaringan komputer memungkinkan terjadinya komunikasi antar pengguna, baik untuk teleconference maupun untuk mengirim pesan atau informasi yang penting lainnya.

3. Integrasi Data

Jaringan komputer dapat mencegah ketergantungan pada komputer pusat, karena setiap proses data tidak harus dilakukan pada satu komputer saja, melainkan dapat didistribusikan ke tempat lainnya. Oleh sebab inilah maka dapat terbentuk data yang terintegrasi yang memudahkan pemakai untuk memperoleh dan mengolah informasi setiap saat.

4. Pengembangan dan Pemeliharaan Pengembangan peralatan dapat dilakukan dengan mudah dan menghemat biaya, karena setiap pembelian komponen seperti printer, maka tidak perlu membeli printer sejumlah komputer yang ada tetapi cukup satu buah karena printer itu dapat digunakan secara bersama-sama. Jaringan komputer juga memudahkan pemakai dalam merawat harddisk dan peralatan lainnya, misalnya untuk memberikan perlindungan

terhadap serangan virus maka pemakai cukup memusatkan perhatian pada harddisk yang ada pada komputer pusat.

5. Keamanan Data

Sistem Jaringan Komputer dapat memberikan perlindungan terhadap data. Karena pemberian dan pengaturan hak akses kepada para pemakai, serta teknik perlindungan terhadap harddisk sehingga data mendapatkan perlindungan yang efektif.

6. Sumber Daya Lebih Efisien dan Informasi Terkini

Dengan pemakaian sumber daya secara bersama -sama, akan mendapatkan hasil yang maksimal dan kualitas yang tinggi. Selain itu data atau informasi yang diakses selalu terbaru, karena setiap ada perubahan yang terjadi dapat segera langsung diketahui oleh setiap pemakai.

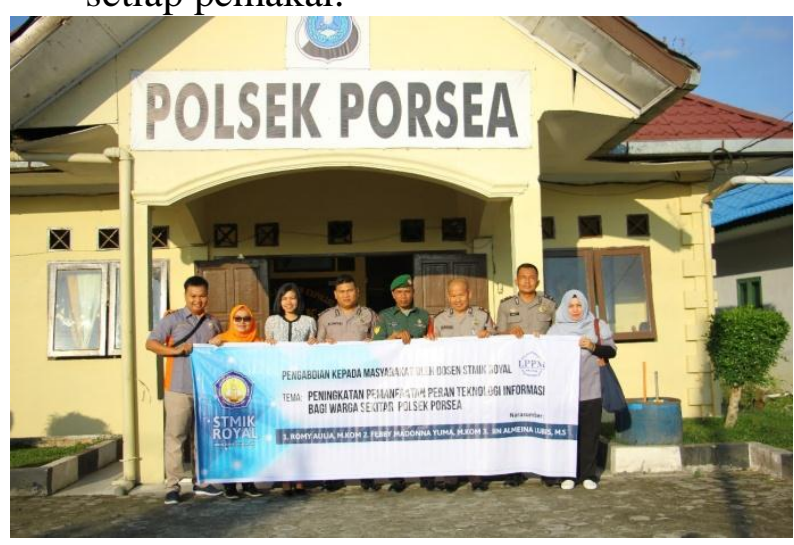

Gambar 1. Tim Abdimas, Kapolsek

Porsea beserta jajarannya dan perwakilan masyarakat sekitar

Beberapa aturan (etika) saat berselancar di internet adalah: 
Jurdimas (Jurnal Pengabdian Kepada Masyarakat) Royal

Vol. 2 No. 2, Juli 2019, hlm. 177 - 180

DOI: https://doi.org/10.33330/jurdimas.v2i2.375

ISSN 2614-7912 (Print)

ISSN 2622-3813 (Online)

Available online at https://jurnal.stmikroyal.ac.id/index.php/jurdimas

1. Amankan dulu diri anda, maksudnya adalah amankan semua properti anda, dapat dimulai dari mengamankan komputer anda, dengan memasang anti virus atau personal firewall

2. Jangan terlalu mudah percaya dengan Internet, sehingga anda dengan mudah mengunggah data pribadi anda. dan anda harus betul-betul yakin bahwa alamat URL yang anda tuju telah dijamin keamanannya.

3. dan yang paling utama adalah, hargai pengguna lain di internet, caranya sederhana yaitu,:

a. jangan biasakan menggunakan informasi secara sembarangan, misalnya plagiat.

b. jangan berusaha untuk mengambil keuntungan secara ilegal dari Internet, misalkan melakukan kejahatan pencurian nomor kartu kredit

c. jangan berusaha mengganggu privasi orang lain, dengan mencoba mencuri informasi yang sebenarnya terbatas.

d. jangan menggunakan huruf kapital terlalu banyak, karena menyerupai kegiatan teriak-teriak pada komunitas sesungguhnya.

e. jangan flamming (memanasmanasi), trolling (keluar dari topik pembicaraan) ataupun junking (memasang post yang tidak berguna) saat berforum.

Dampak negative penggunaan internet antara lain:

1. Tidak peduli dan kurangnya sosialisasi terhadap lingkungan, sehingga kemampuan verbalnya kurang.

2. Boros
3. Merusak kesehatan

4. Kurangnya waktu belajar

5. Kurangnya perhatian untuk keluarga, teman dan kerabat.

6. Tersebarnya data pribadi

7. Mudahnya menemui hal yang berbau pornografi.

\section{SIMPULAN}

Dari hasil kegiatan pengabdian masyarakat ini dapat diambil kesimpulan bahwa pengenalan manfaat dan keuntungan internet berhasil dilaksanakan.

\section{DAFTAR PUSTAKA}

Paryanta.(2016). Media Pembelajaran Sistem Jaringan Komputer Dan Internet Berbantuan Komputer Dengan Model Tutorial.Indonesian Journal on Networking and Security (IJNS). 5 (2) : 1-8

Rini Agustina, S.Kom, M.Pd, (2015), Internet Sehat dan Aman, Jakarta

Yuri., YJ. (2013). Perancangan Program Simulasi

Perintah Dasar Jaringan Komputer.Jurnal Ilmiah Foristek. 3 (2) : 294-301 